\title{
How to Read English Research Articles: A Case Study of Graduate Students Majoring in Information Systems
}

\author{
Krismiyatia, \\ ${ }^{a}$ Satya Wacana Christian University, Indonesia
}

\begin{abstract}
Reading research articles in English will be a special challenge for those students who speak English as a foreign language (EFL). EFL graduate students will require a specific method for helping them to cope with the articles they have to read. This study tries to offer a method for helping them to read, understand, and analyze English articles easier. This study employs evaluation and trialing. It is accompanied by pre and post surveys that will give information about the condition of the students before and after the method is implemented. This study involved graduate students majoring in Information Systems at Satya Wacana Christian University. It is expected that the method proposed will help the students to know exactly what they need to read and focus on when they read a research article so that they can use their time more efficiently and effectively.
\end{abstract}

\begin{abstract}
Abstrak
Membaca artikel riset berbahasa Inggris merupakan tantangan tersendiri bagi mahasiswa penutur Bahasa Inggris sebagai bahasa asing. Mereka membutuhkan metode khusus untuk memahami artikel yang mereka baca. Penelitian ini menawarkan suatu metode sehingga mahasiswa lebih mudah membaca, memahami, dan menganalisis artikel berbahasa Inggris. Penelitian ini menggunakan teknik evaluasi dan percobaan; diawali dan diakhiri dengan kuesioner untuk mengetahui kondisi mahasiswa sebelum dan sesudah metode ini diterapkan. Responden penelitian ini adalah para mahasiswa jurusan Sistem Informasi Universitas Kristen Satya Wacana. Diharapkan metode ini akan membantu mahasiswa mengetahui dengan pasti apa yang harus dibaca dan berkonsentrasi ketika membaca artikel sehingga mereka dapat memanfaatkan waktu secara lebih efektif dan efisien.
\end{abstract}

Key Words: English as a Foreign Language, Scientific Writing, Evaluation, English Research Articles

\section{Introduction}

Reading and analyzing scientific literature, such as textbooks, journals, or research publications, is an inherent part of life for graduate students. They need to be able to keep up with the latest developments in their chosen fields. Technology grows rapidly, and there could always be new creations or inventions.

* Corresponding author.

Address: Satya Wacana Christian University, Jl. Diponegore, 52-60 Salatiga, 50711 Central Java. Email:krismi@staff.uksw.edu.
A recent policy made by the Indonesian Higher Education Directorate regarding postgraduate student publications, which states that students have to publish their work in a nationally recognized journal, has made an impact on many graduate students. Therefore, postgraduate students in Indonesia have to start thinking about publication planning.

Apart from that, publication opens up the opportunity for students to share their work internationally, if possible. In order to publish their work internationally, students need to familiarize themselves with international publications by researching journals or joining international seminars so that their work could be published. 
This is also the case with the students involved in this study. The students involved in this study are postgraduate students majoring in Information System Management at Satya Wacana Christian University.

This study takes place in the participants' pre-session English course in which they have to anticipate their coming work, which will require them to use English at least for reading. They will be exposed to English in their reading assignments, as most of the teachers will assign them to read scientific literature, such as journal articles, as references for writing papers or broadening their knowledge in their field. Besides, the students need to keep up to date with the latest developments in their field. John Flowerdew (1993) says that English is the international language for science publication, including Information Technology. Most of the developments in this area are published in English.

The objective of this study is to find out how to best teach non-English department students how to read research articles. It is expected that this study will give suggestions as to how to address this question, bearing in mind that the field of Information System Management uses English for accessing content or knowledge. In addition, students need to learn how to read effectively and efficiently to achieve what they need in supporting their academic life during their study.

\section{English for Academic Reading Purposes}

University students whose medium of instruction is not in English, even though they have to read English research articles, need specific reading skills. They need to have reading comprehension in English. Normally, they will have what is known as English for Academic Purposes (EAP). With EAP, students will be equipped with strategies that might be useful in real-life situations, which include reading course content in English. Whether they realize it or not, they will be required to employ all their metacognitive skills, as well as their background knowledge, in order to comprehend what they are reading.

Elana Spector-Cohen, Michal Kirschner, and Carol Wexler (2001) designed an EAP reading course for university students that were required to read an extensive bibliography in English but perform any related assignments in their first language. The researchers succeeded in designing syllabi using a global approach that considered the proficiency level of the students. This approach has been successfully implemented considering students' needs. It was proven that those students' reading abilities and knowledge of vocabulary in English improved. Ideally, EAP reading should mainly focus on meaning rather than linguistics (Spector-Cohen et al. 2001).

Bearing in mind what has been discussed regarding EAP, it is important to think seriously about the material used in class. As this study will deal with research articles, it is important to select a wellchosen article. When EAP is implemented properly, then it will be able to meet the subject matter objectives of the course (Wenk and Tronsky 2011). It will contribute to the subject knowledge obtained by the students. It will improve students' ability in reading and increase students' vocabularies.

In order to expose the students to the appropriate authentic material that serves its function in the context of EAP, a specific type of material should be chosen. The EAP situation in this study is the fact that students will need the skill of reading research or journal articles to support their study. The awareness of students towards research or journal article is required.

\section{Research Articles}

Research articles are one kind of academic writing widely accessed by university students, including graduate students (Paltridge 2001). Research articles also serve as a means for students to communicate and share in a discourse community they belong to as practitioners, researchers, educators or other members (Swales 1990). In addition, research articles provide a way for members of any discourse community to participate actively in an international academic discourse community, due to the globalization of science and technology (Chang and Kuo 2011).

Students need to understand the features of research articles so they can become familiar with this 
specific academic genre. Typically, research articles have a structure that distinguishes them from other types of genre (Swales 2004). In general, research articles will have a common structure consisting of Introduction, Methodology, Results/Discussion and Conclusion. This traditional structure is often referred to as the IMR/D structure (Swales 1990). This structure may vary from one area of study to another. One field may have all the elements of structure, while others may not, such as computer science. This field is more flexible, and it does not conform to this traditional structure (Posteguillo 1999).

\section{Introduction}

The introduction is often considered the most troublesome and tricky section, as it has to offer the reader a great deal of information on the area of study in a limited space (Swales 1990; Huckin and Olsen 1991). In addition, it gives the reader an idea of what is being addressed in the study. In line with that, the introduction describes the contribution of the writer to either the past or the present study in a similar area.

The well-known term for an introduction is Creating a Research Space (CARS) (Swales 1990). In this section, the writer establishes an area to introduce the topic of the study being conducted, give justification for and describe the present study.

The introduction is the section in which the identified problem is described. Generally, this section describes how the research article is being presented to the reader, and contains a presentation of the article's overall structure. In addition, the introduction is usually not an easy part for the researcher to start. In general, it is easier to continue writing than to start writing (Swales 1990).

\section{Methodology}

The methodology section is where the researcher usually describes the method employed in the study. This section presents all the technical words that might not be familiar for people from outside of the discourse community (Swales 1990; Kanokshilapatham 2005). The methodology section also gives information to the reader about how the study is being conducted, including information about the participants, the technology being used, and the exact procedure on how the study is conducted.

The methodology section is the place where members of the particular discourse community can easily jump from one part to the next without any difficulty, using their knowledge and experience in that field (Swales 1990). In the more advanced sciences, this section normally offers a method that is not easily replicated compared to "softer science," such as social science (Swales 1990). This section is where the readers see how the study is conducted in order to solve the identified problem and how their proposed solution is carried out in an explicit way.

\section{Results and Discussion}

These two sections are sometimes offered in either one larger section or written separately (Swales 2004). Generally, this section describes all the findings or results clearly. This is the place where the members of a particular discourse community reflect on their sense of membership. They could see the representation of what has been discovered through the study.

Swales (2004) mentions that the results and discussion sections are where the researcher outlines all the findings or results in detail. Furthermore, researchers place the findings or results in the context of the literature being discussed in order to show if their work has proven all the theories that they described in the literature review.

\section{Conclusion}

The conclusion generally offers a summary of the result of the study. It sometimes provides suggestions for further research or applicable implication of the study (Posteguillo 1999). Not every research article has a conclusion section (Swales 1990). However, in his study, Santiago Posteguillo (1999) indicates that research articles, particularly those in the field of computer science, include conclusions as the last section. In this section, the researcher concludes with whether they have answered the posed research 
problems described in the introduction. The conclusion is normally the brief section that readers often look at to see what the study has achieved.

\section{Methodology}

This study employs a trialing and evaluation method. By trying out a strategy or method with particular students, a teacher may infer that what he or she has tried works well in one situation or another (Wallace 2006). Considering this point then, this study tries to do trialing and evaluation. The evaluation itself is carried out after the first trial attempt to see whether what has been proposed works as expected.

Before the trial session is done, a pre-survey is completed to get information. This survey gives a clearer idea on what components should be included in the proposed strategy, which is in this case is the designed template for reading a research article published in an academic journal: a template of taking notes containing a number of article components such as introduction, methodology, results, discussion, title, abstract, etc.

After the trial session the evaluation of the designed template is done. The revised template is then used for reading a different research article. After trying out the revised template, participants will complete a post-survey. The purpose of this postsurvey is to get information on whether or not there is a difference or any improvement in their reading. The pre- and post-surveys use open-ended questions. There is also an informal interview and small discussion session held to collect additional information not obtained through the survey.

\section{Participants}

Ten participants are involved in this study. They are graduate students in their pre-sessional English program, majoring in Information System Management. This study takes place at the Faculty of Information Technology, Satya Wacana Christian University. At this stage, students are usually required to join the program covering programming, database management and English. They have various backgrounds from their previous studies, varying from economics to electrical engineering, informatics engineering to agriculture. The students have different English proficiency levels as well; some of them are more advanced than others. In general, however, they already have taken English classes since high school, as required by the Indonesian curriculum.

In conducting this study, all of the participants were ensured that their responses would be anonymous for the sake of confidentiality and to avoid harm to the participants. Before the survey was distributed to the participants, it was explained that they would not be forced to participate in answering the survey given to them. It was entirely up to the students to participate or not. In addition, the participants were assured that confidentiality was strictly implemented during the data collection and analysis. In presenting the analysis and findings, there were no names mentioned. Participants also signed an informed consent that they would participate in this study.

\section{Pre-Survey}

These are the questions covered in the pre-survey, which is done at the beginning of the research. After the students fill in the survey they are given a session on research article introduction so that they can recognize the typical features of research articles. Some of the things they were asked to identify include the following:

- What is the frequency of which you read research and journal articles?

- What is the field of the research involved in the article you read?

- How do you feel about having to read an English research article?

- Which part of the research article did you read for the first time?

- What is the most important part of the research article?

- What happened when you encountered difficult vocabulary?

- How many times did you have to read the English research article before you really understood it? 
By filling out the pre-survey, information regarding their existing experience with reading research articles could be obtained. This information will be useful later on for creating the template. The product expected at this stage is the template that the students will use in their reading activity.

\section{Post-Survey}

The post-survey is intended for getting information on the students' opinions about reading English research articles using the designed template, which is already revised according to their needs. These are the questions covered in the post-survey:

- What is your opinion on reading an English research articles after using the provided template?

- What strategies did you use when you came across a section you could not understand while reading?

- How many times did you need to read to get what you need from the research article?

\section{Results and Discussion}

\section{Pre-Survey Results}

After the pre-survey is carried out, information on the students' previous experience with reading research articles is obtained. Most of them say that they rarely read any journal or research articles during their undergraduate study. They mentioned that they read a research article related to their field of study once or twice during their undergraduate research.

Since each student's background of study is different, they usually read research articles that correspond to their study. Regarding their opinions on how they feel when they have to read an English research article, they stated that it is indeed a challenging activity. However, there was a quite interesting response about reading English research articles. In their opinion, reading an English research article is more convincing than reading research articles written in Indonesian because it gives them opportunities to get the latest information on developments in the field of information technology.

Discussing the part of research articles that they read for the first time when they were given one, the students gave quite various answers. Some of them read the title and the abstract of the research article. Others said that they directly read the introduction to know what the research article was about. Another answer that was provided was that they go straight to any figures or charts, as they can easily read this part compared to other sections.

When asked about the most important part of research articles, most of the students mentioned the abstract, the methodology section, and the results. They agreed that these sections are the most important part of research articles. After the pre-survey was completed, the information on what to include in the template was determined. In addition, the information was obtained from the informal interview and discussion during the session. The teacher and the students agreed to include the following for each research article:

- Complete citation, including author(s), date of publication, title, journal title, volume number, issue number, and number of pages;

- Website URL and when it was accessed, if applicable;

- Key words;

- General subject of the research article;

- Specific subject of the research article;

- Objectives of the research;

- Methodology;

- Results;

- Important figures, including brief notes about the figures and some information that students think important and that might be useful for their work later on; and

- Cited references to follow up.

The next stage was trying out the designed template for reading a given research article. The students read the same article at home and discussed their work in class with the teacher. The purpose of the discussion was to check whether students got what they needed from the template. Figure 1 
provides a sample template that a student completed after reading an assigned article.

In the template that the students used, some of them wrote additional information that they considered important; sometimes they used Indonesian language in filling out the template. It was not a problem for the teacher because the main purpose here is that students understand the research article that they read.

At the discussion stage, students gave suggestions regarding features that the template may be lacking, including information that they need when they read any research article in their field, especially when the research article is in English. Students suggested that the template needs feature on vocabulary. The vocabulary will comprise all the difficult vocabulary words they might find during their reading apart from those they find in key words list.

Students also suggested that they needed a section on comments in which they can write any comments they want to make while reading. The students were able to put any citation they wanted to make in this section. The last part that students expected when they had the template was a space for suggesting further research. They thought this was important during their reading because it was something that might trigger their curiosity in doing similar work or research. They also believed that this part can give them insight on topics they could research.

With all these suggestions, the template was then revised to accommodate students' needs. Figure 2 provides an example of what students have done with the revised template. At this stage, students were given different research articles to read using the revised template.

\section{Post-Survey Results}

The post-survey was administered after the trial sessions to collect information on participants' condition after using the designed template. When the students were asked about their opinions on reading an English research article, they gave different responses. With the template, they said that they were more focused and had a clearer sense of direction when they had to read a research article.

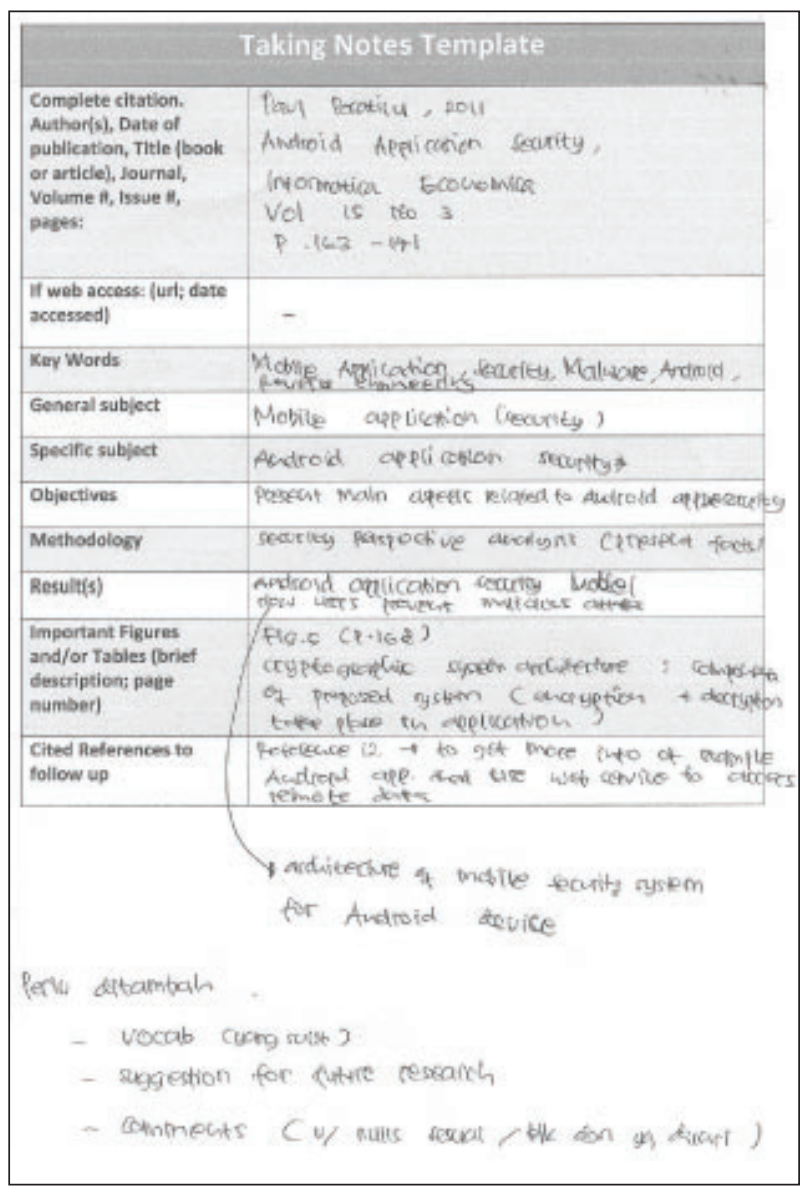

Figure 1. A sample template completed by a student Source: Krismiyati (2013).

One student said, "It is clearer now what I have to look for when I read. I can be more focused" (S1). Another student said, "[Reading] is much easier now. I just need to read what is needed to complete the template" (S3).

In general, the students said that they know exactly which part or section they have to read to find the intended information. If in the pre-survey students said that they normally skip the difficult vocabularies or just look them up in the dictionary for the meaning, after using the template they found strategies for coping with difficult vocabularies as they meet them in the research article they read.

When the students found any difficult vocabulary words, they continued their reading to see if the context or any additional information would help them in deducing the meaning of the difficult words. If 


\begin{tabular}{|c|c|}
\hline \multicolumn{2}{|c|}{ Fesearch Article Note Iakthis } \\
\hline 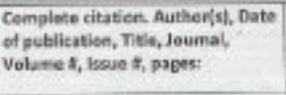 & 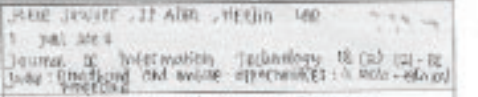 \\
\hline If web actens [urt dane accersed] & 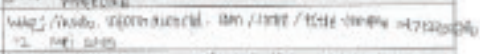 \\
\hline Key Wands & 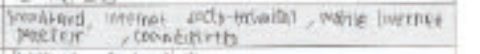 \\
\hline Generai subject & 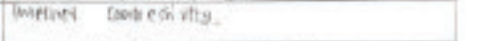 \\
\hline Specilic ounjinet & Iordisyd nud mejice heenet \\
\hline Objectives & 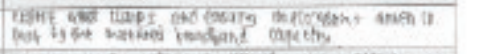 \\
\hline Mathodelosy & 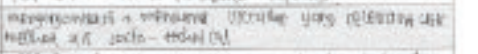 \\
\hline Result(t) & 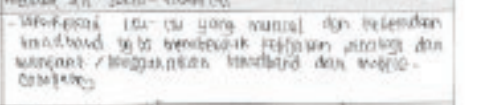 \\
\hline $\begin{array}{l}\text { Impertant fieures / Tables (brief } \\
\text { descriptios; page number) }\end{array}$ & 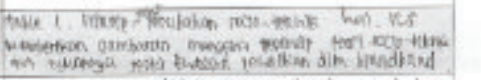 \\
\hline Chat Realerences to fellow up & 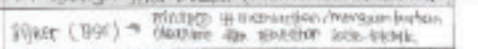 \\
\hline Vocabiary & 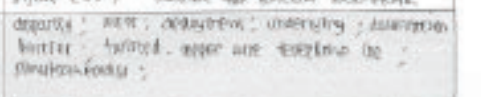 \\
\hline Susgestion for further raseanch & 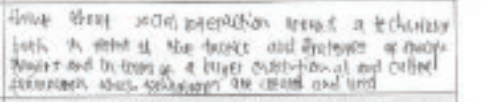 \\
\hline Commentis) & 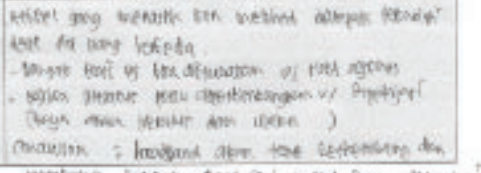 \\
\hline 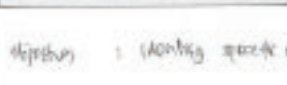 & 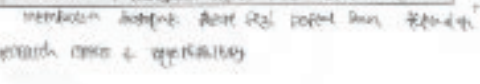 \\
\hline 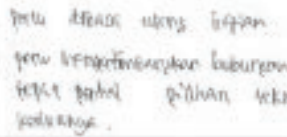 & 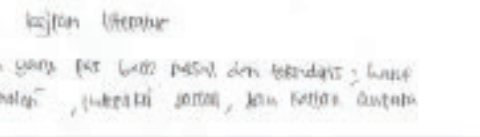 \\
\hline
\end{tabular}

Figure 2. Revised template completed by a student Source: Krismiyati (2013).

they still could not deduce the meaning from the context, they underlined the difficult vocabulary words and continued reading. This was important because looking up difficult vocabulary words often derailed their understanding of a particular text. Afterwards, they looked up the meaning of the vocabulary words and put them in the context of the reading they were doing. They also used the information and the content related to the difficult vocabulary words so that they can know the correct meaning of the words in that particular context.

The last question regarding the frequency of reading after using the designed template that has been agreed on was that students need less time to read. On average, now they just need up to three times reading to understand the research article. This is a progress that they think is quite useful.

\section{Conclusion}

Having a template that consists of what the students need and want really helps them in accelerating their reading. Accelerating, in this context, means that students need a shorter amount of time to read any research article compared to not using the template as they have done previously. It cuts off the time spent reading they have to do. It also helps change their opinion about reading English research articles. They start with the statement saying English research articles are difficult and hard to understand and end up stating that they are easier, clearer, and they are more focused on what they have to read and look for.

Involving students in designing the template indirectly helped them in addressing their concerns and needs. What the teacher might think is important to include in the template might not be the case for the students. It also answers what students want when they are reading any research article. Apart from the advantage they get from using the template for reading research articles in terms of saving students' time, it also helps the students familiarize themselves with the features of research articles as one form of academic writing that they will have to deal with during their studies.

\section{References}

Chang, Ching-Fen and Chih-Hua Kuo. 2011. "A Corpus-Based Approach to Online Materials Development for Writing Research Articles." English for Specific Purposes 30 (3): 222-234.

Flowerdew, John. 1993. "An Educational, or Process, Approach to the Teaching of Professional Genres." ELT Journal 47 (4): 305-316.

Huckin, Thomas N., and Leslie A. Olsen. 1991. Technical Writing and Professional Communication for Nonnative Speaker of English. Singapore: McGrawHill.

Paltridge, Brian. 2001. "Linguistic Research and EAP Pedagogy." In Academic Discourse, ed. John Flowerdew and Matthew Peacock. Cambridge: Cambridge University Press. 
Posteguillo, Santiago. 1999. "The Schematic Structure of Computer Science Research Article." English for Specific Purposes 18 (2): 139 -160.

Spector-Cohen, Elana, Michal Kirschner, and Carol Wexler. 2001. "Designing EAP Reading Courses at the University Level." English for Specific Purposes 20 (4): 367-386.

Swales, John Malcolm. 2004. Research Genres: Exploration and Application, ed. Michael H. Long and Jack C. Richard. Cambridge: Cambridge University Press.

Swales, John Malcolm. 1990. Genre Analysis, eds. Michael H. Long and Jack C. Richard. Cambridge: Cambridge University Press.

Wallace, Michael J. 2006. Action Research for Language Teachers. Cambridge: Cambridge University Press.

Wenk, Laura, and Loel Tronsky. "First-Year Students Benefit From Reading PrimaryResearch Articles." Journal of College Science Teaching 40 (4): 60-67. 